\title{
Functional and cost-benefits of geosynthetics as subgrade reinforcement in the design of flexible pavement
}

\author{
S. Vijayasimhan Sivapriya ${ }^{1}$ \\ Shanmugam Ganesh-Kumar²
}

Fecha de recepción: 9 de diciembre de 2018

Fecha de aprobación: 14 de marzo de 2019

\begin{abstract}
The vertical stress exerted by the vehicles will be high in a populated road and to increase the bearing capacity of subgrade characteristics, geosynthetic material can be used. In the current study different geosynthetic material such as geo-grid, geo-textile and geo-membrane were used to as a subgrade reinforcement member inside the CBR mould for understanding the improvement in subgrade for single, two and three geosynthetic layering in the CBR mould. The results show there was a constant increase in the bearing with the increase in a number of layers and this improvement varied with type of geosynthetic materials also. Among three geosynhteic materials, geogrid shows improved CBR characteristics. Finally, Cost analysis and design of flexible pavement were carried for an optimum number of layers for geogrids. There was reduction of about $6.38 \%$ in the cost of construction when using geogrid as subgrade reinforcement member.
\end{abstract}

Keywords: artifical fiber; bearing estimation; cost analysis; fiber reinforced polymer; membranes; road transportation.

\section{Funcionalidad y costo-beneficio del uso de geosintética como refuerzo de} subgrado en el diseño de pavimento flexible

\section{Resumen}

La tensión vertical ejercida por los vehículos será alta en una carretera poblada y, para aumentar la capacidad de carga de las características de subrasante, se puede usar material geosintético. En el presente estudio, se usaron diferentes materiales geosintéticos, como geo-rejilla, geo-textil y geomembrana, como elemento de refuerzo de subrasante dentro del molde CBR para comprender la mejora en subgrado para capas simples, dos y tres geosintéticas en el molde CBR. Los resultados muestran que hubo un aumento constante en el rodamiento con el aumento en varias capas y esta mejora también varió con el tipo de materiales geosintéticos. Entre los tres materiales geosintéticos, la geomalla muestra características CBR mejoradas. Finalmente, el análisis de costos y el diseño de pavimento flexible se llevaron a cabo para un número óptimo de capas para geomallas. Hubo una reducción de alrededor del $6.38 \%$ en el costo de construcción al usar la geomalla como miembro de refuerzo de subrasante.

\footnotetext{
${ }^{1} \mathrm{Ph} . \mathrm{D} . \mathrm{SSN}$ College of Engineering (Chennai, India). ORCID: 0000-0002-9818-1393.

2 Ph. D. CBRI- IIT Roorkee (Uttarakhand, India). ganeshkumar@cbri.res.in. ORCID: 0000-0001-9424$\underline{9162 .}$
} 
Functional and cost- benefits of geosynthetics as subgrade reinforcement in the design of flexible pavement

Palabras clave: análisis de costos; estimación de rodamientos; fibra artificial; membranas; polímero reforzado con fibra; transporte por carretera.

\section{Funcionalidade e custo-benefício do uso de geossintética como reforço de subgrau no desenho de pavimento flexível}

\section{Resumo}

A tensão vertical exercida pelos veículos será alta em uma estrada povoada e, para aumentar a capacidade de carga das características de subleito, pode-se usar material geossintético. No presente estudo, usaram-se diferentes materiais geossintéticos, como geogrelha, geo-têxtil e geo-membrana, como elemento de reforço de subleito dentro do molde CBR para compreender a melhora em subgrau para camadas simples, dois e três geossintéticas no molde CBR. Os resultados mostram que houve um aumento constante no rolamento com o aumento em várias camadas e esta melhora também variou com o tipo de materiais geossintéticos. Entre os três materiais geossintéticos, a geomalha mostra características CBR melhoradas. Finalmente, a análise de custos e o desenho de pavimento flexível foram realizados a um número ótimo de camadas para geomalhas. Houve uma redução de aproximadamente $6.38 \%$ no custo de construção ao usar a geomalha como membro de reforço de subleito.

Palavras chave: análise de custos; estimação de rolamentos; fibra artificial; membranas; polímero reforçado com fibra; transporte por estrada.

\section{Para citar este artículo:}

S. V. Sivapriya, and S. Ganesh-Kumar, "Functional and cost- benefits of geosynthetics as subgrade reinforcement in the design of flexible pavement," Revista Facultad de Ingeniería, vol. 28 (51), pp. 39-49, Abr. 2019. DOI: https://doi.org/10.19053/01211129.v28.n51.2019.9082.

Esta obra está bajo licencia internacional Creative Commons Reconocimiento 4.0

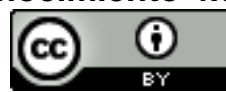




\section{INTRODUCTION}

Geosynthetic, a man-made material generally available in the form of geogrids, geonets, geotextiles, geopipe, geofoam and geomembrane. Depending upon the requirements, Figure 1 shows the main function of the geosynthetic material [1]: a) Separator: When placed between two different materials and provide long-term stress barrier; b) Reinforcement: For stabilising the soil to provide better tensile strength; c) Containment of Barrier: To prevent the leachate in a landfill; d) Filtration: For retaining fine particle on its upstream, and, Drainage: Allows fluid flow through the material.

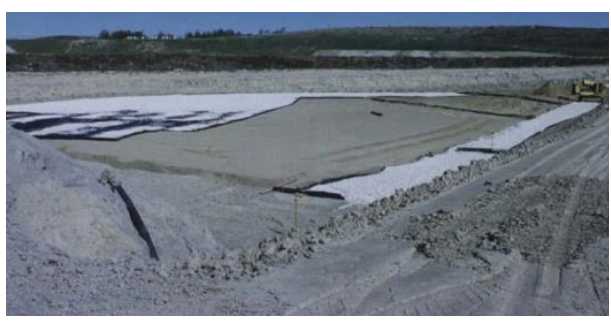

a. Separation

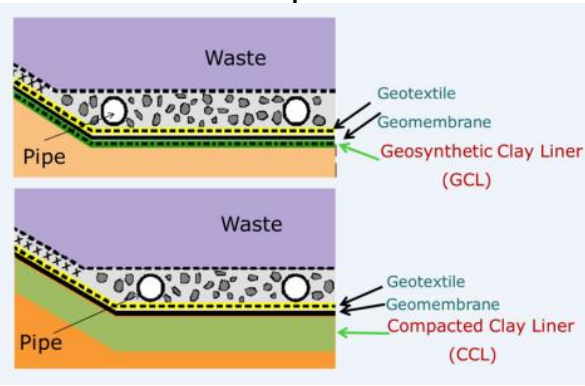

c. Containment of Barrier

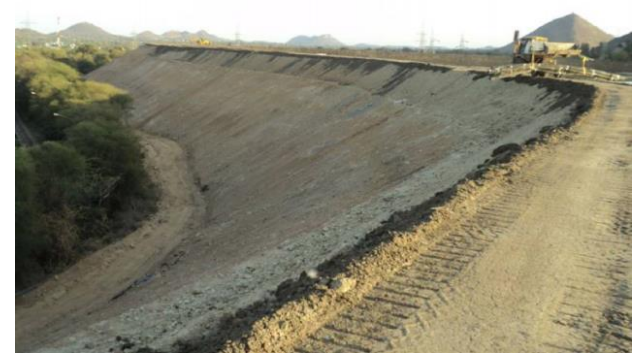

b. Reinforcement

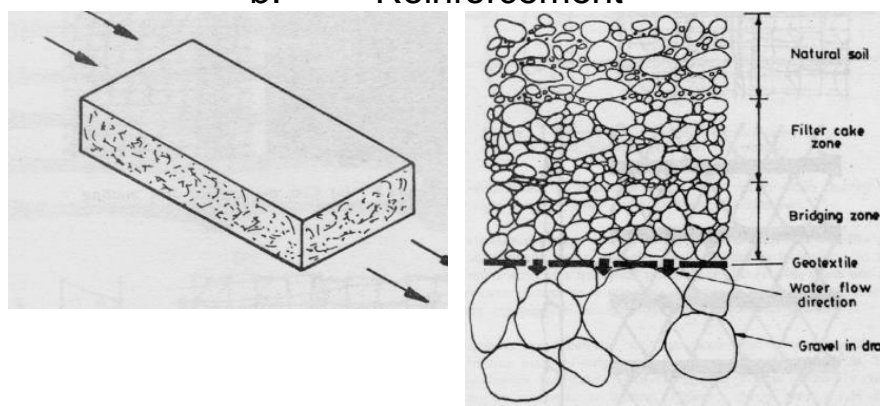

d.Drainage and Filtration

Fig. 1. Functions of Geosynthetics [2-3].

With the increase in population, the road traffic has tremendously increased. The increase in vehicle movement generate high vertical load to the subgrade soil and in soft to medium soil conditions, the soils were unable to withstand the vertical pressure excited by the wheels; this leads to failure or formation of cracks in the pavements. In flexible pavement, the stress developed on the paved road can be reduced by placing the Stress Absorbing Membrane Interlayer (SAMI) which provides a tensile force to reduce the crack; apart from increasing the bearing of the road, it also reduces rutting [2-3]. Figure 2 shows the reduction of cracks paved road with and without geosynthetic. Geosynthetic is also used as a separator to prevent fine soil migrating into base-course and further layers [4].

Field study, laboratory study and numerical studies emphasised the use of geosynthetic material in pavement of soft clay and dense sand ground [5-14]) under static loading and literature shows the importance of geosynthetic under cyclic loading to reduce the vertical stress and deformations [15-17]. This manmade material can also be used under foundation [18-20] to increase the bearing capacity of the soil. 
Form the above study, it was clear that geosynthetic material reinforces the soil to give increased bearing pressure. To have a comparative study between the geosynthetic materials, a laboratory study was conducted to understand the influence of various geosynthetic material say geogrid, geotextile and geomembrane in CBR value. However, geomembrane used as a separator was considered for comparative study. Cost analysis was also carried out for the optimum condition.

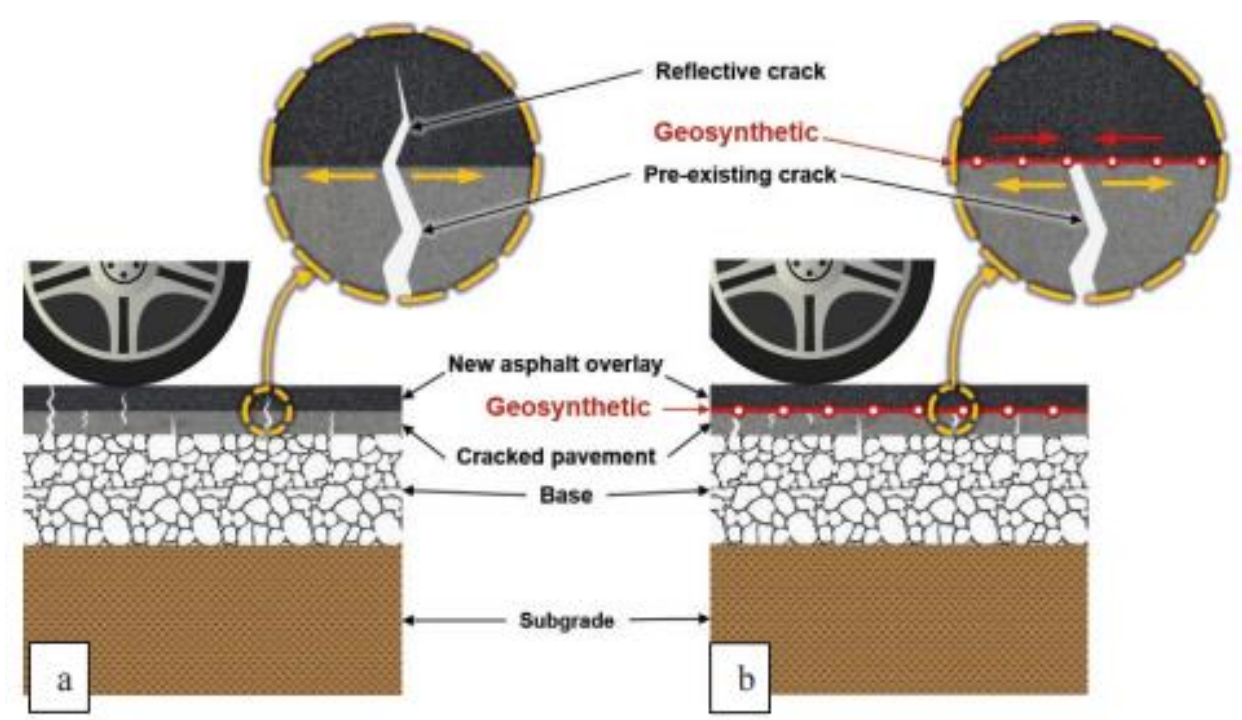

Fig. 2. Flexible road a) without geosynthetic and b) with geosynthetic [23].

\section{MATERIALS AND METHODS}

\section{A. Material property}

The soil used was collected from Thadagam Road, Coimbatore, India and its various index and physical engineering properties of the soil were tabulated in Table 1 using Indian Standard codes [21-25]. The properties of the geosynthetic were tabulated in Table 2.

Table 1. Properties of the soil.

\begin{tabular}{ll}
\hline Property Description & Values \\
\hline Speific gravity ,G & 2.7 \\
Optimum moisture content (\%) & 14 \\
Unit weight of soil,y $\left(\mathrm{kN} / \mathrm{m}^{3}\right)$ & 18.2 \\
Particle Size $\quad$ Gravel & 1.6 \\
$\quad$ Sand & 44.1 \\
$\quad$ Silt & 12.22 \\
$\quad$ Clay & 42.08 \\
Liquid Limit, WL (\%) & 52 \\
Plastic Limit, $\mathrm{W}_{\mathrm{p}}(\%)$ & 15.78 \\
Plasticity Index, I $(\%)$ & 36.22 \\
Shrinkage Limit, $\mathrm{W}_{\mathrm{s}}(\%)$ & 6.32 \\
Shrinkage Index, Is (\%) & 45.68 \\
Cohesive Strength, $\mathrm{C}_{\mathrm{u}}\left(\mathrm{kN} / \mathrm{m}^{2}\right)$ & 31.25 \\
Angle Of Shearing Resistance, $\phi(\mathrm{deg})$ & 14 \\
Classification & $\mathrm{CH}$ \\
\hline
\end{tabular}


Table 2. Geosynthetic Material property.

\begin{tabular}{lccc}
\hline Property & Geotextile & Geomembranes & Geogrid \\
\hline Thickness $(\mathrm{mm})$ & 1.5 & 0.3 & 0.9 \\
Wide width tensile strength $(\mathrm{kN} / \mathrm{m})$ & 14 & 56 & 60 \\
Elongation $(\%)$ & 55 & 12 & 2 \\
Opening size $(\mathrm{mm})$ & 0.085 & 0.5 & - \\
\hline
\end{tabular}

\section{B. California Bearing Ratio (CBR)}

California bearing ratio was conducted as per IS 2720 - part 16 [26] in a 155 $\mathrm{mm}$ diameter and $175 \mathrm{~mm}$ height. The soil was prepared at optimum moisture content for a disturbed sample under dynamic compaction to a height of 125 $\mathrm{mm}$ and surcharge plate was placed during loading. The test was conducted for both unsoaked and soaked for 4 days' condition. The bearing ratio was found using equation (1); the value of $2.5 \mathrm{~mm}$ penetration and $5 \mathrm{~mm}$ penetration was calculated. For $2.5 \mathrm{~mm}$ penetration, the standard load is $1370 \mathrm{~kg}$ and for $5 \mathrm{~mm}$ penetration, it is $2055 \mathrm{~kg}$.

$$
\mathrm{CBR}=\frac{\text { Corrected test load corresponding to } 2.5 \text { or } 5 \mathrm{~mm} \text { penetration }}{\text { unit standard load for the same depth of penertation }} \times 100 \%
$$

\section{Parameter study}

California bearing ratio (CBR) tests were carried with geogrid, geotextile (nonoven type) and geomembrane and compared with results of soil alone. Table 3 shows the parametric study involved.

Table 3. Parametric Study with notation.

\begin{tabular}{llll}
\hline \multirow{1}{*}{ Material } & Layers & \multicolumn{2}{c}{ CBR } \\
\cline { 3 - 4 } & & Unsoaked & Soaked \\
\hline Soil Alone & S1 & S2 \\
Soil +Geogrid & Single & S1GG1 & S2GG1 \\
& Two & S2GG2 & S2GG2 \\
& Three & S1GG3 & S2GG3 \\
Soil+Geotextile & Single & S1GT1 & S2GT1 \\
& Two & S1GT2 & S2GT2 \\
& Three & S1GT3 & S2GT3 \\
Soil+Geomembrane & Single & S1GM1 & S2GM1 \\
& Two & S1GM2 & S2GM2 \\
& Three & S1GM3 & S2GM3 \\
\hline
\end{tabular}

\section{Sample preparation}

The fine-grained soil of $4.5 \mathrm{~kg}$ was mixed with an optimum moisture content of $14 \%$ was dynamically compacted in five layers with 56 blows by a hammer weight of $4.89 \mathrm{~kg}$. Geogrid, geotextile and geomembrane were cut to the diameter of the mould. For single layer, the material it was kept at the middle of the mould, for two spacing it was placed at a $1 / 3^{\text {rd }}$ height and for three-layer it was placed at a $1 / 4^{\text {th }}$ height of the mould (Figure 3 ). 


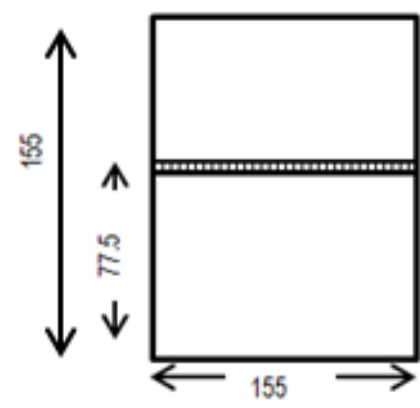

a. Single layer

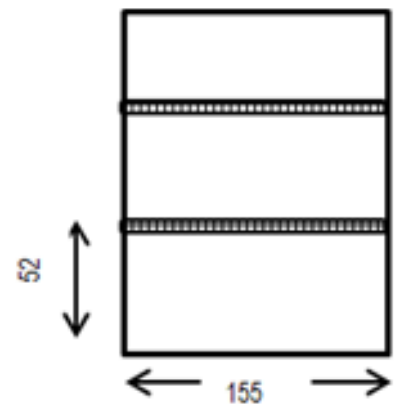

b. Two-layer

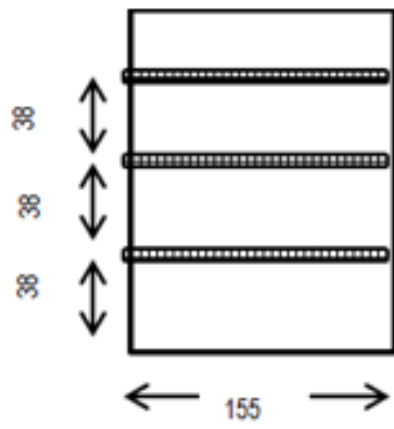

c. Three Layer
Dimensions are in $\mathrm{mm}$. Drawn not to scale

Fig. 3. Schematic representation of location of geomaterial for testing.

\section{RESULTS AND DISCUSSION}

Load corresponding to 2.5 and $5 \mathrm{~mm}$ for unsoaked condition was 38.57 and $49.09 \mathrm{~kg}$ respectively; the corresponding CBR value was calculated as $2.82 \%$ and $2.38 \%$. The CBR value was observed for soaked condition for 2.5 and 5 $\mathrm{mm}$ penetration was calculated as 2.3 and 2.21 for a load of 31.56 and $45.59 \mathrm{~kg}$ respectively. There was a reduction in CBR between unsoaked and soaked condition was by $18.44 \%$ and $7.14 \%$ for 2.5 and $5 \mathrm{~mm}$ penetration respectively; as $2.5 \mathrm{~mm}$ penetration value was higher than the $5 \mathrm{~mm}$ value the former value was considered for CBR calculation (Figure 4).

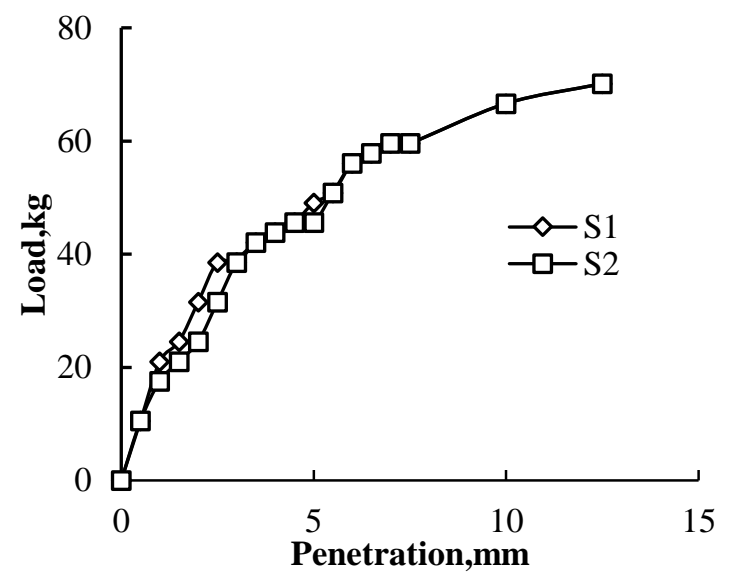

Fig. 4. Penetration characteristics of soil.

\section{A. Influence of geogrid}

The geogrid was placed at the mid of the CBR column and loaded till $14 \mathrm{~mm}$ penetration. A comparative representation was shown in figure 5 for an unsoaked and soaked condition for various geogrid conditions. There was increase in CBR value increases to $58.18 \%, 78.44 \%$ and $79.31 \%$ for single, double and three layers respectively. The increase in bearing ratio was doubled with the introduction of geogrid in the soil for a single layer. For two and three layers of geogrid, the CBR value was increased to $73.44 \%$ and $79.31 \%$ respectively. The difference was less between two and three layer as the stress overlap between the segregation of soil layers and geogrids. 


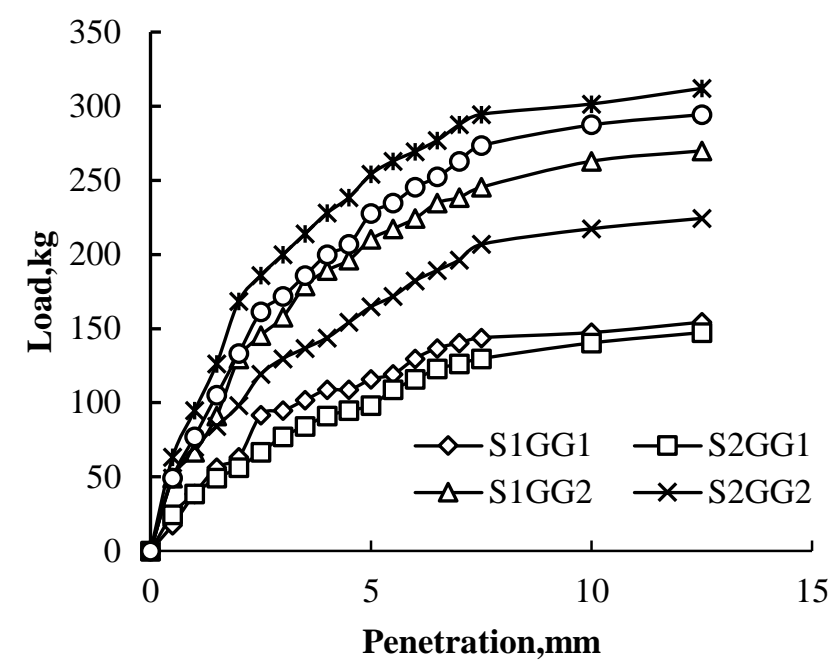

Fig. 5. Penetration behaviour for various of Geogrid layers.

\section{B. Influence of geotextile}

Geotextile was also placed in mid as single, two and three layers. There was an increase in bearing ratio by $50.09 \%, 67.7 \%$ and $77.08 \%$ when compared to unsoaked soil alone. Under soaked condition, the bearing ratio increased to $39.95 \%$ and $84.11 \%$ for single and two layers; when three layers were placed the bearing had reduced to $76.81 \%$. It was observed that the bearing ratio decreased to $76.81 \%$ when three layers of geotextile were placed (Figure 6).

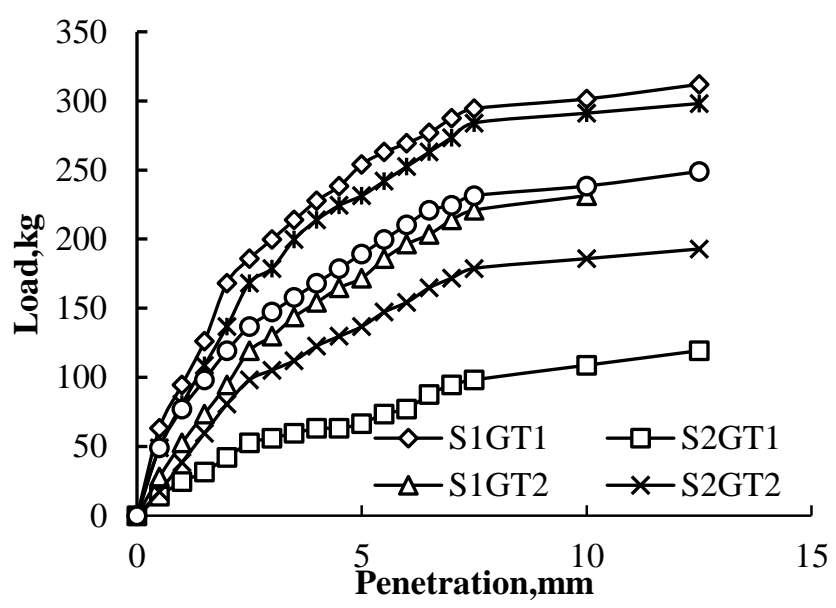

Fig. 6. Penetration behaviour for various of Geotextile layers.

\section{Influence of geomembrane}

The geomembrane when placed in middle of the mould, the bearing ratio increases to $58.18 \%, 73.44 \%$ and $79.31 \%$ under unsoaked condition when compared to virgin soil. After soaking it, the CBR value increases to $39.51 \%$, $84.11 \%$ and $76.81 \%$ for different layers (Figure 7 ). 


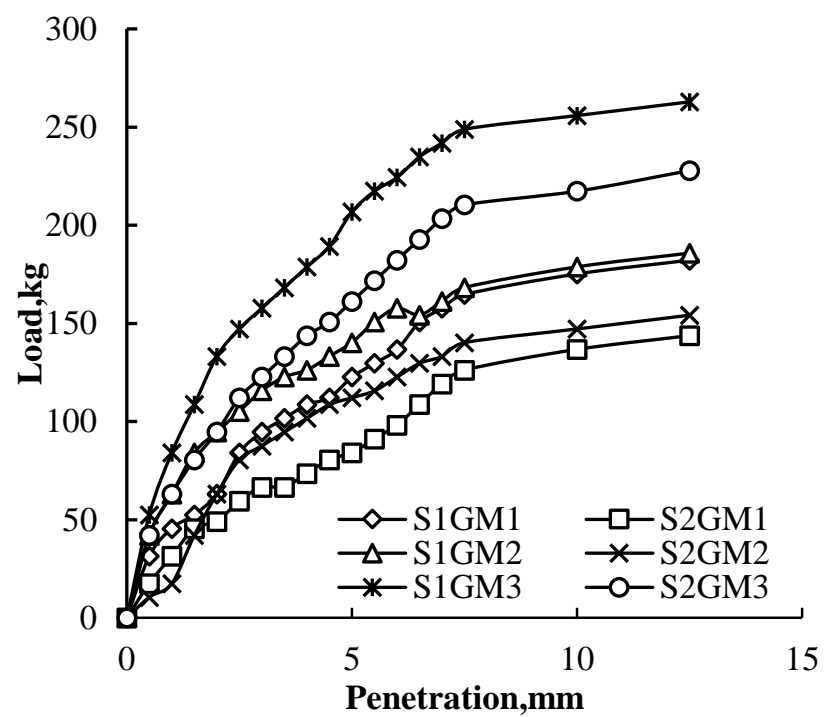

Fig. 7. CBR Value of Geomembrane for various layers.

\section{Reinforcement Ratio (RR)}

Reinforcement ratio (ratio of the load with the geosynthetic to the load without the geosynthetic material), for unsoaked and soaked specimen there was calculated. Figure $8 a$ shows the $R R$ value for selected penetration level; RR value was high around $2.5 \mathrm{~mm}$ penetration and there was a sudden decrease beyond that [27-28]. It was clearly visible that soaked CBR value with three layers of geogrid followed by geotextile and geomembrane showed maximum value compared to two and single layers of the respective material. However, the maximum CBR value considered for design is limited to $9 \%$.

In Figure 8b unsoaked and soaked RR value was plotted for $2.5 \mathrm{~mm}$ penetration and it ranges from 1.66 to 5.09 , mostly soaked values were less than that of the unsoaked values expect in case of three layers of geogrids; similar to the observations of Fannin and Sigurdsson [29]. For geogrid it shows higher value because of its stiffer characteristics, followed by geomembrane and then geotextile. As the ratio value was greater than one, it implies that the geogrid material can be used for subgrade material to increase the penetration load characteristics.

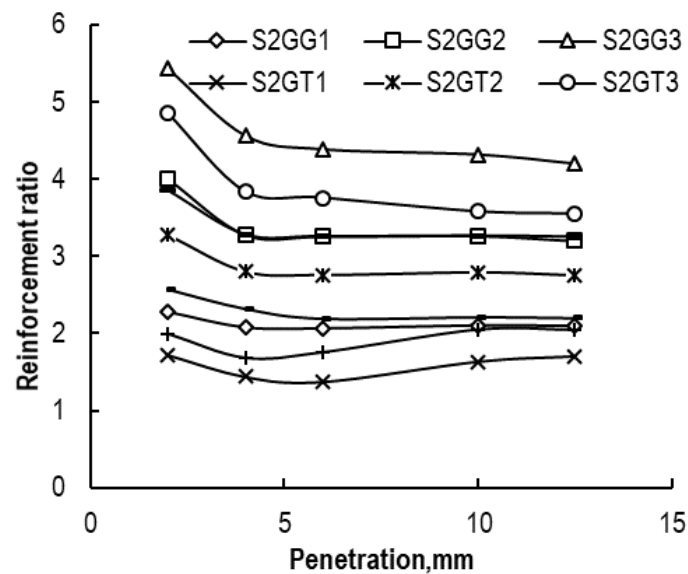

a) RR for various penetration

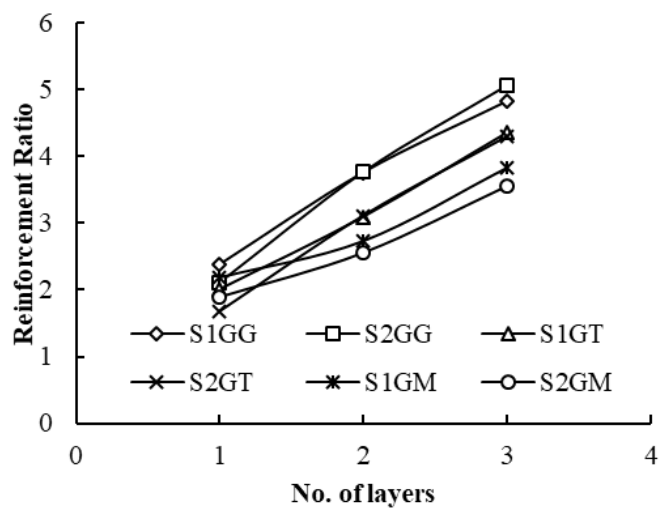

b) RR for various layer at $2.5 \mathrm{~mm}$ penetration

Fig. 8. Reinforcement ratio of various geosynthetic layers. 
Functional and cost- benefits of geosynthetics as subgrade reinforcement in the design of flexible pavement

\section{E. Cost analysis}

As per IRC 37-2000 [30], if the CBR value exceeds $10 \%$ the thickness of pavement is not affected majorly. For triple layers of geogrids, the CBR value for unsoaked and soaked value was 13.57 and 11.68 values respectively; hence two layers of geogrids under soaked condition was chosen for design of pavements.

A flexible pavement was designed (Figure 9) and its thickness of each layer was tabulated in Table 4. Cost analysis was done for soaked two layers of geogrids using equation (2) and the following input parameter was considered.

Cumulative number of standard axles to be catered for design $(\mathrm{N})$ in msa:

$$
N=\frac{365\left[(1+r)^{n}-1\right]}{r} A D F
$$

Where, $r$ - annual growth rate (\%), $n$ - design life (years), A -initial traffic (cv/day), D- lane distribution factor, F- vehicle damage factor.

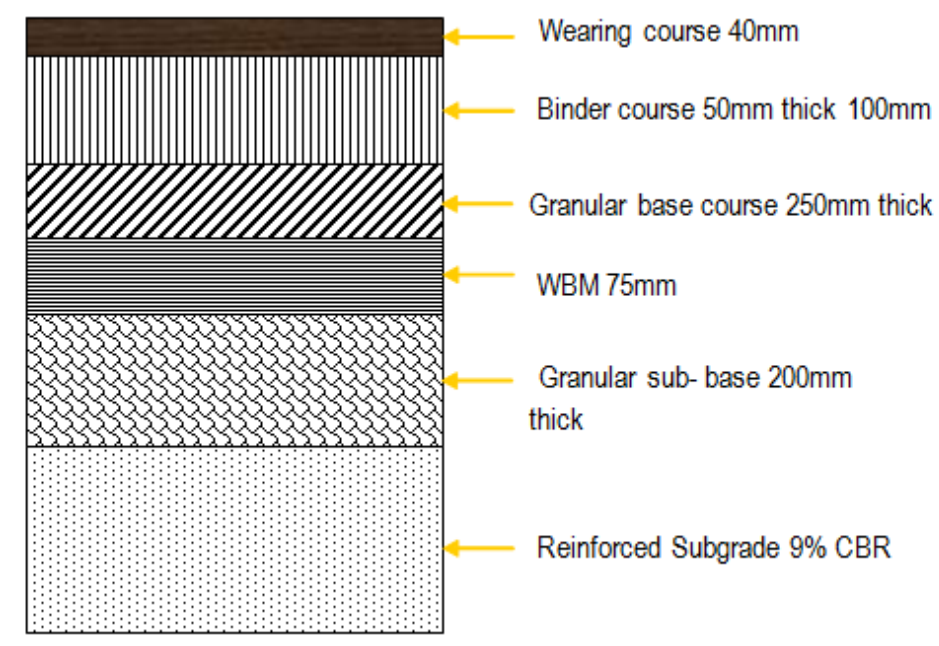

Fig. 9. Flexible pavement.

Table 4. Design layer thickness.

\begin{tabular}{lcc}
\hline Properties & For unreinforced Soil & Geogrid + two layers \\
\hline CBR Value, \% & 2 & 9 \\
Plate Type & 1 & 1 \\
Thickness & 850 & 540 \\
Granular sub-base course, mm & 460 & 200 \\
Granular base course, mm & 250 & 200 \\
Binder course,mm & 100 & 50 \\
Wearing course,mm & 40 & 40 \\
\hline
\end{tabular}

Two lanes single carriageway with $500 \mathrm{cv} /$ day with $7.5 \%$ of traffic growth rate per annum with 15 years of design life with vehicle damage factor of 2.5 standard axles per commercial vehicles and CBR value of $8.66 \%$ with lane 
distribution factor as $0.75 \mathrm{D}$. Table 5 shows the break-up of various thickness of layer.

Difference in cost estimation for reinforced and unreinforced subgrade

Estimated cost for unreinforced subgrade for $1 \mathrm{~km}$ stretch=

Estimated cost for reinforced subgrade for $1 \mathrm{~km}$ stretch=

Estimated cost of two layers of geogrid $(2 \times 200000)=$
Rs. $88,99,805.00$

Rs. $79,31,942.00$

Rs. $4,00,000.00$

$$
\begin{array}{lll}
\text { Cost difference } \quad=\quad \text { Rs. } 5,67,863.00
\end{array}
$$

The data were obtained from Public Works Department estimated cost chart and there was reduction around 8218.63 USD (in percentage $=6.38 \%$ ).

Table 5. Cost analysis.

\begin{tabular}{|c|c|c|c|c|}
\hline \multirow[t]{2}{*}{ S.No. } & \multirow[t]{2}{*}{ Nature of work } & \multirow{2}{*}{$\begin{array}{l}\text { Cost calculation for } \\
1 \mathrm{~km} \text { stretch }\end{array}$} & \multicolumn{2}{|c|}{ Cost in Rupees } \\
\hline & & & $\begin{array}{c}\text { For } \\
\text { unreinforced } \\
\text { Soil }\end{array}$ & $\begin{array}{c}\text { Geogrid + two } \\
\text { layers }\end{array}$ \\
\hline 1 & Excavation & $1000 \times 7 \times 0.85 \times 79.31$ & $4,71,894$ & $2,99,792$ \\
\hline 2 & $\begin{array}{l}\text { Compaction of original ground } \\
\text { supporting subgrade }\end{array}$ & $1000 \times 7 \times 0.5 \times 147.5$ & $5,16,250$ & $5,16,250$ \\
\hline 3 & Cost for subbase course layer & $1000 \times 7 \times 0.46 \times 368$ & $11,84,960$ & $5,15,200$ \\
\hline 4 & Cost for base course layer & $1000 \times 7 \times 0.25 \times 2590$ & $45,32,500$ & $45,32,500$ \\
\hline 5 & Cost for binder course layer & $1000 \times 7 \times 0.1 \times 2360$ & $16,52,000$ & $8,26,000$ \\
\hline 6 & Cost for wearing course layer & $1000 \times 7 \times 0.04 \times 2590$ & $7,25,200$ & $7,25,200$ \\
\hline 7 & $\begin{array}{l}\text { Cost for tack coat over BM } \\
\text { layer }\end{array}$ & $1000 \times 7 \times 8.2$ & 57,400 & 57,400 \\
\hline \multirow[t]{3}{*}{8} & Cost for prime coat layer & $1000 \times 7 \times 22.8$ & $1,59,600$ & $1,59,600$ \\
\hline & TOTAL IN RUPEES & & $88,99,805$ & $79,31,942$ \\
\hline & TOTAL IN USD & & 128806.88 & 114799 \\
\hline
\end{tabular}

\section{CONCLUSION}

Geogrid and geotextiles were most commonly adopted material to increase the bearing of the soil. The presence of a geosynthetic layer in, or at the bottom of the base can resulted in minimum stress and strain transfer in to the subgrade. In case of flexible pavements, where there is a less stiff subgrade material lies beneath the layer of subbase course, improvement in modulus of the base or subbase layer resulted in improved, more broadly distributed vertical stress on the subgrade. Hence in this study, an attempt is made to study the effect of subgrade layer reinforced with different geosynthetics. Three different geosynthetic materials were selected and reinforced with three types of spacings for reinforcing the subgrade. The geosynthetics were installed at middle of compacted subgrade, double spacing at $1 / 3^{\text {rd }}$ layer of compacted subgrade, and triple spacing at the $1 / 4^{\text {th }}$ layer of the compacted subgrade. The following are the conclusions arrived from the study for soaked values mainly,

- California bearing ratio of unreinforced soil under unsoaked condition was found to be $2.8 \%$ and under soaked conditions, it's about $2.3 \%$, which indicates the poor status of the subgrade material for $2.5 \mathrm{~mm}$ 
Functional and cost- benefits of geosynthetics as subgrade reinforcement in the design of flexible pavement

penetration and there was a reduction in CBR value by $17.86 \%$ for soaked condition compared with unsoaked condition.

- The CBR value ranges as 4.86, 8.69 and $11.68 \%$ for geogrids, for geotextiles it ranges as $3.83,7.17$ and $9.93 \%$ and for geomembranes $4.35,5.89$ and $8.19 \%$ for single, double and triple layers respectively. Test results shown that, the subgrade layer reinforced with geogrid shows higher CBR values than geotextile and geomembrane for all the reinforcement layers because of its stiffness and the strength characteristics.

- When positioning geogrid as reinforcement layer, the apertures in geogrid helps in developing effective interlocking mechanism, holding soil together and improves redistribution of load over a wider area.

- The maximum CBR value adopted for designing the flexible pavement is $9 \%$, beyond which there will be no significant reduction in the thickness of the pavement layer. Considering this, geogrid with double layer spacing was considered as the optimum type and positioning of material.

- For the unreinforced subgrade CBR value the thickness required as per IRC: $\mathbf{3 7 - 2 0 0 1}$ was $850 \mathrm{~mm}$ whereas when using the geosynthetic material as subgrade reinforcement the thickness was reduced to $\mathbf{5 4 0}$ $\mathrm{mm}$. This reduces the cost of around around 8000 USD amouting to $6.4 \%$ compared to the unreinforced soil in pavement.

- The reinforcement in subgrade layer resulted in developing adequate stiffening which resulted in reduction of thickness and time of construction. This also helps in increasing the life of the pavement.

\section{REFERENCES}

[1] J. Zornberg, "Advances in the use of geosynthetics in pavement design," in Second National Conference on Geosynthetics, 2011, pp. 3-21.

[2] S. J. Webster, S. L. Alford, "Investigation of construction concepts for pavements across soft grounds," Waterways Experiment Station, Vicksburg,Miss, 1978.

[3] J. A. Ramalho-Ortiago, and E. M. Palmiera, "Geotextile performance at an access road on soft ground near Rio de Janeiro," Proc. 2nd Int. Conf. Geotext., vol. 1, pp. 353-358, 1982.

[4] Amara Loulizi, Imad L Al-Qadi, Salman A.Bhutta, Gerardo W.Flintsch, "Evaluation of Geosynthetics used as Separators," Transportation Research Record, vol. 1687 (1), pp. 104-111, Jan. 1999. DOI: https://doi.org/10.3141/1687-12.

[5] K. Huntington, and G. Ksaibati, "Evaluation of geogrid reinforced granular base," Transp. Res. Board, vol. 18 (1), pp. 22-28, 2000.

[6] J. Jenner,C,Paul, "Lesson learned from 20 years experience on geosynthetic reinforcement of pavement foundtions," in 2nd European geosynthetics conference, 2000, pp. 421-426.

[7] X. Collin, J. G. Kinney, and T. C. Fu, "Full Scale Highway Load Test of Flexible pavements systems with geogrid reinforced base course," ICE Virtual Libr., vol. 3 (4), pp. 537-549, 1996. DOI: https://doi.org/10.1680/gein.3.0074.

[8] F. Chan, R. D. Barksdale, and S. F. Brown, "Aggregate base reinforcement of surfaced pavements," Geotextiles and Geomembranes, vol. 8 (3). pp. 165-189, Jan. 1989. DOI: https://doi.org/10.1016/0266-1144(89)90002-2.

[9] Q. C. Murrad, Y. Abu-Farskh, and I. Akond, "Evaluating the performance of geosynthetic-reinforced unpaved roads using plate load tests," Int. J. Pavement Eng., vol. 17 (10), pp. 901-912, 2015.

[10] S. Bloise, and N. Ucciardo, "On site test of reinforced freeway with high strength geosynthetics," Transp. Res. Board, vol. 1, pp. 369-371, 2000.

[11] R. Hufenus, R. Rueegger, R. Banjac, P. Mayor, S. M. Springman, and R. Brönnimann, "Full-scale field tests on geosynthetic reinforced unpaved roads on soft subgrade," Geotextiles and Geomembranes, vol. $24 \quad(1), \quad$ pp. 21-37, Feb. 2006. DOI: https://doi.org/10.1016/i.geotexmem.2005.06.002.

[12] L. G. Palmeria, and E. M. Antunes, "Geosynthetic reinforced unpaved road performance after surface maintenance," in 9th International COnference on Geosynthetics, 2010, pp. 1457-1460.

[13] U. Rajesh, S. Sajja, and V. K. Chakravarthi, "Studies on Engineering Performance of Geogrid Reinforced Soft Subgrade," Transportation Research Procedia, vol. 17, pp. 164-173, 2016. DOI: https://doi.org/10.1016/j.trpro.2016.11.072. 
[14] K. K. Babu, "Utilisation of Coir Geotextiles for Unpaved Roads and Embankments," Doctoral Thesis, Cochin University of Science and Technology, Kochi, India, 2007.

[15] A. K. Ashmawy, and P. L. Bourdeau, "Response of a Woven and a Nonwoven geotxtile to monotonic and cyclic simple tension," ICE Virtual Libr., vol. 3 (4), pp. 493-515, 1996.

[16] A. M. Elleboudy, N. M. Saleh, and A. G. Salama, "Assessment of geogrids in gravel roads under cyclic loading," Alexandria Engineering Journal, vol. 56 (3), pp. 319-326, Sep. 2017. DOI: https://doi.org/10.1016/..aej.2016.09.023.

[17] L. Suku, S. S. Prabhu, and G. L. Sivakumar Babu, "Effect of geogrid-reinforcement in granular bases under repeated loading," Geotextiles and Geomembranes, vol. 45 (4), pp. 377-389, Aug. 2017. DOI: https://doi.org/10.1016/j.geotexmem.2017.04.008.

[18] M. T. Das. B. M. Shin, and E. C. Omar, "The bearing capacity of surface strip foundations on geo-grid reinforced sand and clay - a comparative study," Geotech. Geol. Eng., vol. 12 (1), pp. 1-7, Mar. 1994. DOI: https://doi.org/10.1007/BF00425933.

[19] E. Cicek, E. Guler, and T. Yetimoglu, "Effect of reinforcement length for different geosynthetic reinforcements on strip footing on sand soil," Soils and Foundations, vol. 55 (4), pp. 661-677, Aug. 2015. DOI: https://doi.org/10.1016/j.sandf.2015.06.001.

[20] M. Salih Keskin, and M. Laman, "Experimental and numerical studies of strip footings on geogridreinforced sand slope," Arab. J. Sci. Eng., vol. 39 (3), pp. 1607-1619, Mar. 2014. DOI: https://doi.org/10.1007/s13369-013-0795-7.

[21] Bureau of Indian Standard, IS 2720 (Part III/I)-Determinationof Specific Gravity of Fine granied Soil, 1997, pp. 1-10.

[22] Bureau of Indian Standard, IS 2720 (Part V)-Determination of Liquid and Plastic Limit, 1995, pp. 1-17.

[23] Bureau of Indian Standard, IS 2720 (Part IV)-Grain size analysis, 1995, pp. 1-40.

[24] Bureau of Indian Standard, IS 2720 (Part X)-Determination of Unconfined Compressive Strength, 1995, pp. 1-8.

[25] Bureau of Indian Standard, IS 2720 (Part VII)-Methods of Test for Soils, Determination of Water Content-Dry Density Relation using Light Compaction, 2011, pp. 1-16.

[26] Bureau of Indian Standard, IS 2720 (Part 16)-Laboratory Determination of CBR, 1997, pp. 1-17.

[27] C. A. Adams, E. Apraku, and R. Opoku-boahen, "Effect of Triaxial Geogrid Reinforcement on CBR Strength of Natural Gravel Soil for Road Pavements," J. Civ. Eng. Res., vol. 5 (2), pp. 45-51, 2015.

[28] S. A. Naeini, and R. Ziaie-Moayed, "Effect of plasticity index and reinforcement on the CBR value of soft clay," International Journal of Civil Engineering, vol. 7 (2). 2009, pp. 124-130.

[29] R. J. Fannin, and O. Sigurdsson, "Field Observations on Stabilization of Unpaved Roads with Geosynthetics," J. Geotech. Eng., vol. 122 (7), pp. 544-553, 1996. DOI: https://doi.org/10.1061/(ASCE)0733-9410(1996)122:7(544).

[30] IRC 37, "Guidelines for the Design of Flexible Pavements," Indian Roads Congr. New Delhi, 2012. 